\title{
29. STABLE ISOTOPE INVESTIGATIONS OF SEDIMENTS, BASALTS, AND AUTHIGENIC PHASES FROM LEG 35 CORES
}

\author{
T.F. Anderson, Department of Geology, University of Illinois, Urbana, Illinois \\ and \\ J.R. Lawrence, Lamont-Doherty Geological Observatory, Palisades, New York
}

\section{INTRODUCTION}

One of the primary objectives of the geochemical investigations on Leg 35 cores was to evaluate the importance of in situ alteration of primary constituents and genesis of authigenic phases on the stable isotopic compositions of sediments and volcanics. In this paper, we report our preliminary results on the oxygen and the carbon isotopic composition of solid phases and reach some tentative conclusions on the factors that control these compositions, particularly chemical and isotopic interactions with solutions of seawater origin. Some of the results presented in this paper are interpreted in more detail by Lawrence et al., this volume.

\section{ANALYTICAL PROCEDURES}

Sample pretreatment and isotopic analytical methods followed conventional procedures. Bulk samples were disaggregated by crushing in a mortar and pestle. Samples containing both carbonate and noncarbonate phases were divided into two portions. Carbonates were removed from one of the portions by treatment with a buffered sodium acetate-acetic acid solution (Jackson, 1956); the other portion was set aside for carbon and oxygen isotopic analysis of the carbonate phase. All samples were then washed in distilled water, rinsed in methanol, and allowed to dry at room temperature.

Oxygen was extracted for isotopic analysis of silicate phases by the bromine pentafluoride method of Clayton and Mayeda (1963). For analyses performed at Lamont, $\mathrm{O}_{2}$ gas was analyzed directly in the mass-spectrometer. For analyses performed at Illinois, $\mathrm{O}_{2}$ was converted to $\mathrm{CO}_{2}$ for mass-spectrometric analyses. The carbon and oxygen isotopic compositions of carbonates were determined by mass-spectrometric assay of $\mathrm{CO}_{2}$ evolved by reaction with $100 \%$ phosphoric acid at $25^{\circ} \mathrm{C}$ (McCrea, 1950). Isotopic compositions are reported in the $\delta$ notation as per mil deviations from SMOW for oxygen and from PDB for carbon. Average deviations from the mean value of replicate oxygen isotopic analyses of claystones and chert at the Illinois laboratory were approximately 0.3 per mil. The average deviation from the mean value of replicate oxygen isotopic analyses of a standard kaolinite at the Lamont laboratory was better than 0.3 per mil. Repeatability of analyses of clays containing interlayer water, however, was \pm 0.7 to \pm 1.0 per mil. This higher uncertainty may be attributable to incomplete removal of interlayer water during evacuation of the samples.

\section{RESULTS}

The isotopic compositions of all samples analyzed in this study are listed in Tables 1-3. Figures 1-4 are sketches of bulk samples from which two or more components were sampled for isotopic analyses.

Bulk silicate sediments have $\delta \mathrm{O}^{18}$ values ranging from +8.5 to +20.8 per mil (Table 1 ). By comparison, published analyses of deep-sea sediments from other localities are in the range +11.5 to +30.5 per mil (Savin and Epstein, 1970; Yeh, 1974). Silicified claystones, or "cherts," are 8 to 14 per mil enriched in $\mathrm{O}^{18}$ relative to adjacent claystones, indicating that silicification involved the precipitation of $\mathrm{O}^{18}$-rich silica. The variation of $\delta \mathrm{O}^{18}$ in bulk sediments from Site 323 with depth is shown in Figure 5.

Authigenic carbonates from Sites 323 and 325 have $\delta \mathrm{O}^{18}$ values that are several per mil lower than those typical of unaltered pelagic carbonates. The carbon isotopic compositions of these carbonates are about 20 per mil depleted relative to pelagic carbonates and are comparable to the composition of marine organic carbon. The sample of recrystallized nannochalk from Site 325 has a normal oxygen isotopic composition, but a $\delta \mathrm{C}^{13}$ value somewhat lower than unrecrystallized pelagic carbonates. The isotopic data thus suggest that the recrystallization of primary carbonates and the precipitation of authigenic carbonates occurred in waters that were depleted in $\mathrm{C}^{13}$ and probably $\mathrm{O}^{18}$ with respect to normal seawater.

Whole-rock samples of basalt have $\delta \mathrm{O}^{18}$ values ranging from +6.9 to +11.2 per mil. Muehlenbachs and Clayton (1972) demonstrate that unaltered oceanic basalts have compositions in the range +5.5 to +5.9 per mil and that $\delta \mathrm{O}^{18}$ values increase due to reactions with cold seawater to produce clays and other lowtemperature authigenic phases. Evidently, such a lowtemperature "weathering" process has affected all the samples we analyzed to a variable extent. The variation of $\delta \mathrm{O}^{18}$ values of basalts with depth at Site 323 (Figure 6) has an irregular pattern, at least in the upper part, but suggests that $\mathrm{O}^{18}$ contents increase in the top 20 meters and are constant at greater depths (to $31 \mathrm{~m}$ ). Vein-filling carbonates (calcite) in the basalts have $\delta \mathrm{O}^{18}$ values in the range +25.4 to +31.4 per mil and $\delta \mathrm{C}^{13}$ values in the range -3.0 to +2.4 per mil, similar to those of secondary carbonates in oceanic volcanics from numerous other localities (Anderson, in preparation). The variation of $\delta \mathrm{O}^{18}$ in calcite veins with depth at Site 323 is shown in Figure 6 and suggests, with the exception of a large excursion at 705-708 meters, that the compositions approach fairly uniform values of +30 to +31 per mil below the upper 5 meters.

\section{BULK SILICATE SEDIMENTS}

The oxygen isotopic compositions of bulk silicate sediments are generally consistent with their lithologic 
TABLE 1

Isotopic Composition of Siliceous Sediments

\begin{tabular}{llcc}
\hline $\begin{array}{c}\text { Sample } \\
\text { (Interval in cm) }\end{array}$ & \multicolumn{1}{c}{ Description } & $\begin{array}{c}\text { Depth in } \\
\text { Core }(\mathrm{m})\end{array}$ & \multicolumn{1}{c}{$\delta 0^{18}$} \\
\hline $322-11-3,125-128$ & Fine-grained sandstone & 509 & $+10.9^{\mathrm{a}}$ \\
$322-11-4,40-43$ & Silty claystone & 510 & $+12.9^{\mathrm{a}}$ \\
$322-11-5,18-20$ & Claystone & 611 & $+19.9^{\mathrm{a}}$ \\
$322-11, \mathrm{CC}$ & Claystone (10 cm from basalt) & 514 & $+16.8^{\mathrm{a}}$ \\
$323-1-5,0-15$ & Clayey diatom ooze & 84 & $+19.7^{\mathrm{a}}$ \\
$323-3, \mathrm{CC}$ & Diatom-rich clay & 265 & $+17.7^{\mathrm{a}}$ \\
$323-8-1,65-70$ & Diatom-rich clay + quartz clayey silt & 409 & $+12.3 \pm 0.5^{\mathrm{b}}$ \\
$323-8-1,118-121$ & "Chert"- silicified claystone & 410 & $+31.2 \pm 0.4^{\mathrm{b}}$ \\
$323-8-1,125-129$ & Partly silicified claystone & 410 & $+17.1 \pm 0.3^{\mathrm{b}}$ \\
$323-8, \mathrm{CC}$ & "Chert" & 418 & $+29.4 \pm 0.7^{\mathrm{b}}$ \\
$323-9-2,113-118$ & Claystone & 458 & +14.2 to $+15.2^{\mathrm{b}}$ \\
$323-9-2,118-120$ & "Chert" & 458 & +23.3 to $+25.0^{\mathrm{b}}$ \\
$323-10-1,95-100$ & Claystone & 504 & $+13.2 \pm 0.1^{\mathrm{b}}$ \\
$323-10-1,95-100$ & "Chert" & 504 & $+21.1 \pm 0.0^{\mathrm{b}}$ \\
$323-11-1,0-10$ & Quartz silty claystone & 551 & $+14.3^{\mathrm{a}}$ \\
$323-13, \mathrm{CC}$ & Clayey siltstone & 626 & $+13.3^{\mathrm{a}}$ \\
$323-14-2,101-102$ & Fe-claystone' & 638 & $+19.3^{\mathrm{a}}$ \\
$323-15-1,41-42$ & Fe-claystone & 655 & $+18.7^{\mathrm{a}}$ \\
$323-16-4,70-71$ & Claystone & 674 & $+20.8^{\mathrm{a}}$ \\
$323-17-6,133-135$ & Claystone & 683 & $+20.6^{\mathrm{a}}$ \\
$323-18-2,133-134$ & Claystone & 695 & $+18.6^{\mathrm{a}}$ \\
$323-18-6,4-6$ & Zeolitic claystone & 701 & $+19.9^{\mathrm{a}}$ \\
$325-7-2,54-55$ & Noncarbonate residue in nannochalk & 520 & $+20.0 \pm 0.3^{\mathrm{b}}$ \\
$325-10-3,139-142$ & Claystone & 713 & $+8.6^{\mathrm{b}}$ \\
$325-10-3,139-142$ & Clay conglomerate & 713 & $+9.1^{\mathrm{b}}$ \\
\hline & & & \\
\hline & & & \\
& & &
\end{tabular}

Note: $\delta 0^{18}$ values are in per mil relative to SMOW.

a Analyzed at Lamont.

bAnalysed at Illinois.

TABLE 2

Isotopic Composition of Carbonates in Sediment

\begin{tabular}{llcrr}
\hline $\begin{array}{c}\text { Sample } \\
\text { (Interval in cm) }\end{array}$ & \multicolumn{1}{c}{ Description } & $\begin{array}{c}\text { Depth in } \\
\text { Core }(\mathrm{m})\end{array}$ & $\delta 0^{18}$ & $\delta \mathrm{C}^{13}$ \\
\hline $323-13-6,36$ & Authigenic carbonate & 625 & +26.0 & -18.4 \\
$323-13-6,51$ & Authigenic carbonate & 625 & +26.8 & -20.3 \\
$325-7-2,54-55$ & Recrystallized nannochalk & 520 & +31.2 & -4.3 \\
$325-10-3,139-142$ & $\begin{array}{l}\text { Authigenic carbonate matrix } \\
\text { of clay conglomerate }\end{array}$ & 713 & +24.3 & -21.2 \\
& & & \\
\hline
\end{tabular}

Note: $\delta 0^{18}$ values are in per mil relative to SMOW. $\delta \mathrm{C}^{13}$ values are in per mil relative to PDB. All analyses were performed at the University of Illinois.

compositions. Except for the basal 63 meters at Site 323, the isotopic results suggest a terrigenous source for the bulk sediments. Out data imply that the basal sediments at Site 323 contain a high proportion of digenetically altered volcanogenic debris. Most of our samples are from Site 323, and therefore the discussion in this section will emphasize these results.

Four sedimentary units are recognized at Site 323 (see Site Report): Unit 1 (0-266 m) consists largely of gray unconsolidated sandy silt, diatom clays, and diatom oozes. Unit $2(266-506 \mathrm{~m})$ consists of relatively indurated diatomic claystones and silicified claystones or cherts. Unit $3(506-638 \mathrm{~m})$ also consists of gray claystones, but is devoid of biogenic silica. unit 4 (638$701 \mathrm{~m})$ consists of brownish claystones, nanno claystones, and zeolitic claystones.

The abundance of diatoms in Unit 1 is reflected in the relatively high $\delta \mathrm{O}^{18}$ values of the bulk sediments.
Biogenic opaline silica and diagenetic opal C-T and granular-microcrystalline quartz have reported $\delta \mathrm{O}^{18}$ values of +31 to +39 per mil (Mopper and Garlick, 1971; Kolodny and Epstein, 1974; Knauth and Epstein, 1975). The indurated claystones of Unit 2 are similar in mineralogy to the overlying unconsolidated sediments, including the common occurrence of biogenic silica, but have $\delta \mathrm{O}^{18}$ values that are lower by several per mil. Also, the claystones of Unit 3, which are devoid of biogenic silica, have isotopic compositions similar to the claystones of Unit 2. All of the claystones of Unit 2 that we analyzed were from Cores 8-10, where silicified claystones, or "cherts," occur. This suggests that the biogenic silica in these claystones had been mobilized and reprecipitated in adjacent layers to form chert.

The cherts in Cores 8-10 are enriched in $\mathrm{O}^{18}$ by 8-14 per mil relative to adjacent claystones. This enrichment is entirely consistent with a mechanism of chert forma- 
TABLE 3

Isotopic Composition of Basalts and Secondary Vein-Filling Minerals in Basalt from Site 323

\begin{tabular}{|c|c|c|c|c|c|}
\hline $\begin{array}{c}\text { Sample } \\
\text { (Interval in } \mathrm{cm} \text { ) }\end{array}$ & & Description & $\begin{array}{l}\text { Depth in } \\
\text { Core }(m)\end{array}$ & $\delta 0^{18}$ & $\delta C^{13}$ \\
\hline $18-6,17-19$ & \multicolumn{2}{|c|}{ Clay vein } & 700.7 & $+24.2 \pm 0.7^{\mathrm{a}}$ & \\
\hline \multirow[t]{5}{*}{$18-6,73-83$} & $1 b$ & Saponite vein & 701.3 & $+19.6 \pm 0.7^{\mathrm{a}}$ & \\
\hline & 2 & Basalt (slightly altered) & & $+10.3^{\mathrm{a}}$ & \\
\hline & 3 & Basalt (slightly altered) & & $+11.2^{\mathrm{a}}$ & \\
\hline & 4 & Coarsely crystalline calcite & & $+25.4^{\mathrm{a}}$ & $-2.2^{\mathrm{a}}$ \\
\hline & 1a & Calcite impregnated in saponite & & $+25.8^{\mathrm{a}}$ & $-3.0^{\mathrm{a}}$ \\
\hline $19-1,90(\# 1)$ & \multicolumn{2}{|c|}{$\begin{array}{l}\text { Basalt } \\
\text { Carbonate vein }\end{array}$} & 703.4 & $\begin{array}{l}+10.6^{\mathrm{b}} \\
+29.5^{\mathrm{b}}\end{array}$ & $+2.0^{\mathrm{b}}$ \\
\hline $19-2,140(\# 11)$ & \multicolumn{2}{|c|}{$\begin{array}{l}\text { Basalt (relatively unaltered) } \\
\text { Basalt (brown stained) } \\
\text { Carbonate vein }\end{array}$} & 705.4 & $\begin{array}{r}+7.7^{\mathrm{b}} \\
+7.0^{\mathrm{b}} \\
+31.1^{\mathrm{b}}\end{array}$ & $+1.9^{\mathrm{b}}$ \\
\hline \multirow[t]{6}{*}{$19-2,144-146$} & 1 & Basalt & 705.4 & $+7.6^{\mathrm{b}}$ & \\
\hline & 2 & Basalt & & $+7.8^{\mathrm{b}}$ & \\
\hline & 3 & Basalt & & $+6.9^{\mathrm{b}}$ & \\
\hline & 4 & Calcite vein near basalt 3 & & $+31.4^{\mathrm{b}}$ & $+2.4^{\mathrm{b}}$ \\
\hline & 5 & Basalt & & $+7.9^{\mathrm{b}}$ & \\
\hline & 6 & Calcite vein near basalt 5 & & $+29.5^{b}$ & $+2.0^{\mathrm{b}}$ \\
\hline $19-3,17-19$ & \multicolumn{2}{|c|}{ Calcite vein } & 705.7 & $+28.0 \pm 0.1$ & $+1.8 \pm 0.0^{\mathrm{a}, \mathrm{b}}$ \\
\hline \multirow[t]{5}{*}{$19-3,90-92(\# 10)$} & 1 & Green clay vein & 706.4 & $+21.4 \pm 1.0^{\mathrm{a}}$ & \\
\hline & 3 & Basalt near vein & & $+10.2^{\mathrm{a}}$ & \\
\hline & 4 & Basalt & & $+9.8^{\mathrm{a}}$ & \\
\hline & 5 & Basalt (iron stained) & & $+9.7^{\mathrm{a}}$ & \\
\hline & 6 & Basalt & & $+9.7^{\mathrm{a}}$ & \\
\hline $19-4,65(\# 7)$ & \multicolumn{2}{|c|}{ Carbonate vein } & 707.7 & $+26.5^{\mathrm{b}}$ & $+1.8^{\mathrm{b}}$ \\
\hline $19-4,140(\# 19)$ & \multicolumn{2}{|c|}{ Carbonate vein } & 708.4 & +30.2 & $+2.0^{\mathrm{b}}$ \\
\hline $20-1,44-47$ & \multirow{2}{*}{\multicolumn{2}{|c|}{$\begin{array}{l}\text { Basalt } \\
\text { Carbonate vein }\end{array}$}} & 712.5 & $+10.9^{b}$ & \\
\hline & & & & $+30.5^{b}$ & $+2.0^{\mathrm{b}}$ \\
\hline $20-2,60(\# 2)$ & \multicolumn{2}{|c|}{ Basalt } & 714.1 & $\begin{array}{r}+8.7^{\mathrm{b}} \\
+30.8^{\mathrm{b}}\end{array}$ & \\
\hline $20, \mathrm{CC}(\# 1 \mathrm{c})$ & \multicolumn{2}{|c|}{ Basalt } & 721.5 & $\begin{array}{r}+6.9^{\mathrm{b}} \\
+30.8^{\mathrm{b}}\end{array}$ & $+2.2^{\mathrm{b}}$ \\
\hline $21, \mathrm{CC}(\# 1)$ & \multicolumn{2}{|c|}{ Basalt } & 731.0 & $\begin{array}{r}+7.4^{\mathrm{b}} \\
+30.3^{\mathrm{b}}\end{array}$ & $+2.1^{\mathrm{b}}$ \\
\hline
\end{tabular}

Note: $\delta 0^{18}$ values are in per mil relative to SMOW. $\delta \mathrm{C}^{13}$ values are in per mil relative to PDB.

${ }^{a}$ Analyzed at Lamont.

${ }^{b}$ Analyzed at Illinois.

tion involving the precipitation of cryptocrystalline silica. Thus, from the isotopic evidence, silicified claystones are composed of (1) a detrital component (clay minerals, quartz, feldspar) having $\delta \mathrm{O}^{18}=+12$ to +15 per mil and (2) secondary silica having $\delta \mathrm{O}^{18}=+31$ to +39 per mil. The decrease in $\delta \mathrm{O}^{18}$ of the cherts with depth (Figure 5) implies that the proportion of silica also decreases. Interestingly, the concentration of dissolved $\mathrm{SiO}_{2}$ in pore waters also decreases markedly with depth in the lower part of Unit 2 and in Unit 3 (Gieskes, this volume). Sample 323-9-2, 113-120 cm contains a well-defined contact between hard, dark gray chert and soft, $\tan$ claystone. The oxygen isotopic composition of samples of both lithologies at regular intervals $(6-8 \mathrm{~mm})$ away from the contact were determined to examine in more detailed the control of lithology on isotopic composition. The results are shown in Figure 1. At more than $10 \mathrm{~mm}$ from the contact, the isotopic composition of each phase is uniform. Within $10 \mathrm{~mm}$ of the contact, an isotopic gradient is apparent. The isotopic "contact" is not as sharp as the lithologic contact but still readily serves to distinguish between the two lithologic types.

The oxygen isotopic compositions of bulk sediments in Unit 4 are 5-6 per mil enriched in $\mathrm{O}^{18}$ compared to the gray claystones of Units 2 and 3 . Unit 4 consists entirely of brownish claystones. Clay minerals, amorphous iron oxides, and zeolites, which increase in abundance immediately above the basalt, are the primary noncarbonate components; detrital quartz and feldspar were not observed in smear-slide examination. Sediments of this type occur immediately above basement in numerous locations in the equatorial Pacific (see site report). Drever (this volume) presents convincing chemical and mineralogical evidence for a dominantly volcanic source for the sediments in Unit 4 and for a dominantly terrigenous source for the sediments in 


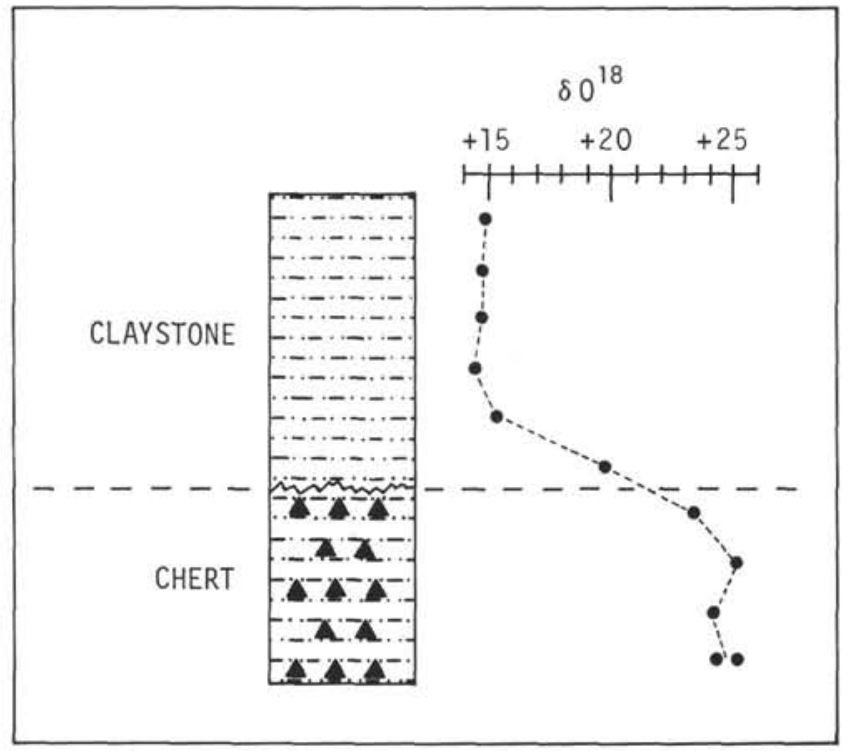

Figure 1. Oxygen isotopic composition of Sample 323-9$2,113-120 \mathrm{~cm} . \delta O^{18}$ values are in per mil relative to SMOW.

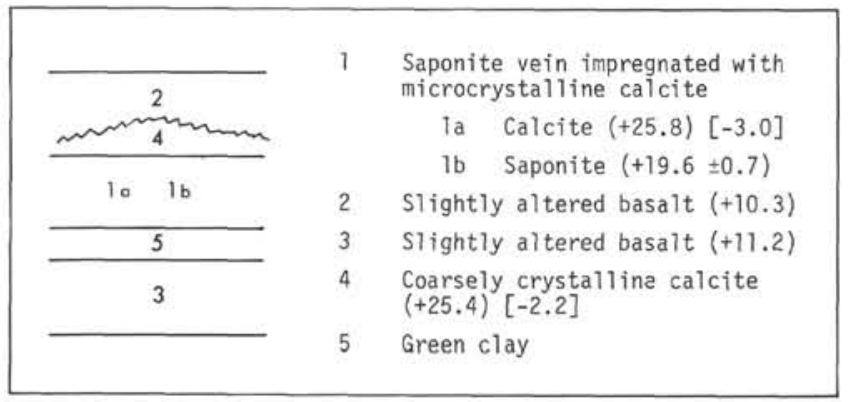

Figure 2. Isotopic composition of Sample 323-18-6, 73$83 \mathrm{~cm} . \delta O^{18}$ values in per mil relative to SMOW are in parentheses. $\delta O^{13}$ values in per mil relative to $P D B$ are in brackets.

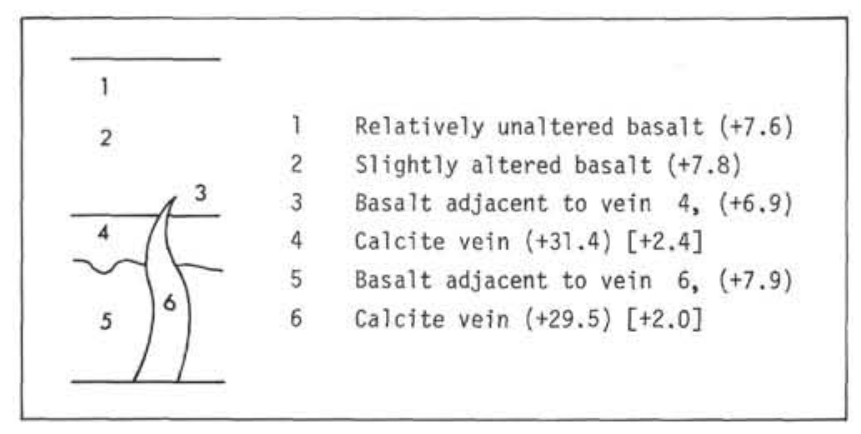

Figure 3. Isotopic composition of Sample 323-19-2, 144 146. $\delta O^{18}$ values in per mil relative to SMOW are in parentheses. $\delta O^{13}$ values in per mil relative to $P D B$ are in brackets.

Units 1-3. Accordingly, the marked enrichment of $\mathrm{O}^{18}$ in the bulk sediments from Unit 4 probably reflects a high proportion of low-temperature alteration products of volcanogenic debris, such as smectites and zeolites.

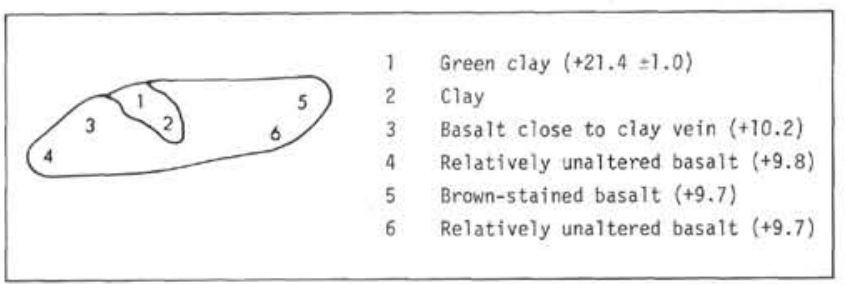

Figure 4. Oxygen isotopic composition of Sample 323$19-3,90-92 \mathrm{~cm} \# 10.80^{18}$ values in per mil relative to SMOW are in parentheses.

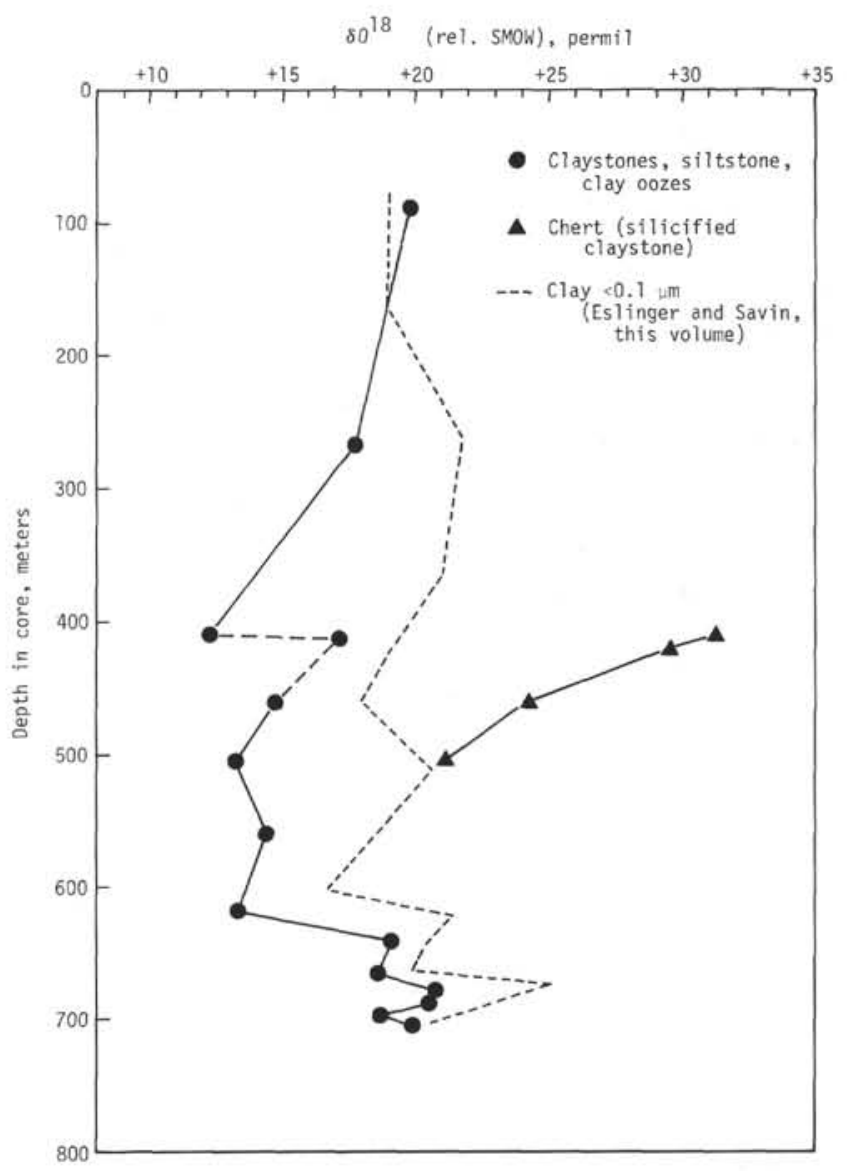

Figure 5. Oxygen isotopic composition of siliceous sediments from Site 323 versus depth in core.

However, this interpretation is not generally consistent with the mineralogic and isotopic data on clay minerals and fine-grained quartz reported by Eslinger and Savin (this volume). They argue that, while diagenesis has altered the proportions of clay minerals and the oxygen isotopic composition of the $<0.1 \mu \mathrm{m}$ size fraction, there is no obvious trend in diagenesis or in the isotopic composition of this size fraction with depth. The implication is that volcanogenic clay minerals are no more abundant below 638 meters than above this depth. Their isotopic data are shown in Figure 5. Above 638 meters, bulk sediments from Units 2 and 3 are several per mil lighter than the $<0.1 \mu \mathrm{m}$ size fractions. This requires that $\mathrm{O}^{18}$-depleted detrital phases, such as feldspar and quartz, are important constituents of the 


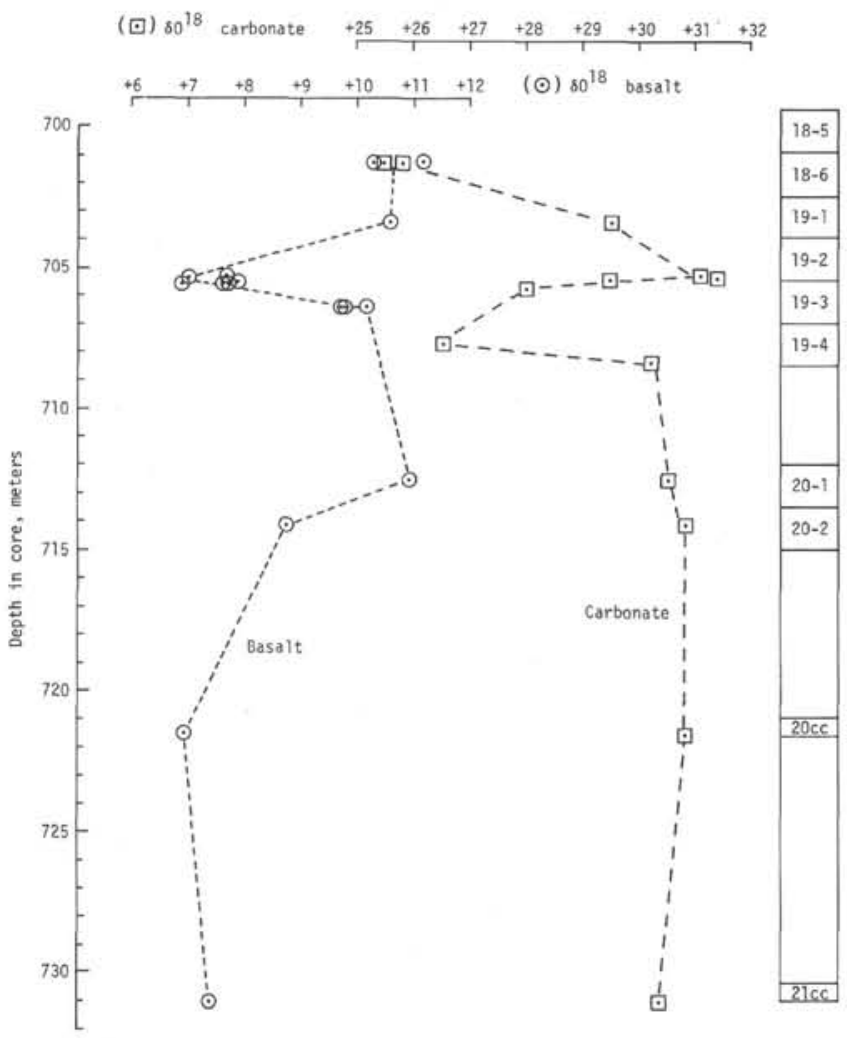

Figure 6. Oxygen isotopic composition of basalts and of carbonate veins in basalt versus depth in core at Site 323. $\delta O^{18}$ values are in per mil relative to SMOW.

bulk sediments. Fine-grained quartz in these sediments have $\delta \mathrm{O}^{18}$ values of +8 to +12 per mil (Eslinger and Savin, this volume). Below 638 meters, there is, in our opinion, the possibility that the $<0.1 \mu \mathrm{m}$ size fraction is slightly enriched in $\mathrm{O}^{18}$ relative to overlying samples. The isotopic composition of the bulk sediments approaches the composition of the $<0.1 \mu \mathrm{m}$ size fraction. This requires that the silt- and sand-size fractions be only slightly depleted in $\mathrm{O}^{18}$ relative to the bulk, and, consequently, consist primarily of diagenetic or authigenic phases. Drever (this volume) reports that the primary minerals in the silt-size fraction of Unit 4 are quartz, K-feldspar, plagioclase, smectite, clinoptilolite, and mica. K-feldspar, smectite, and clinoptilolite are probably products of diagenesis; quartz, plagioclase, and mica probably are not. Eslinger and Savin (this volume) report that fine-grained quartz in Unit 4 sediments have $\delta \mathrm{O}^{18}$ values in the range +8 to +19 per mil, with most values between +8 to +10 per mil. Thus, isotopically light detrital components are definitely present. Their importance in affecting the composition of bulk sediments appears to be small, but this remains to be verified through the analysis of different grain-size fractions in additional bulk samples.

At Site 322, we analyzed four samples of bulk sediment from Core 11, which immediately overlies basalt. Above $11-4,30 \mathrm{~cm}$ the lithology is silty sandstone. Detrital rock fragments, quartz, feldspar, heavy minerals, and clay minerals are the primary constituents. A single bulk sediment isotopic analysis for this unit gave a $\delta \mathrm{O}^{18}$ value of +10.9 per mil, consistent with a terrigenous origin for the sediment. The lower part of Core 11 consists of claystone. In Section 4, clay minerals are abundant but detrital quartz and feldspar are the predominant constituents. The isotopic composition the bulk sediment at $11-4,40-43 \mathrm{~cm}$ is +12.9 per mil, reflecting a predominant terrigenous source. In Sections 5 and 6 and the core catcher, the claystones are composed almost exclusively of clay minerals. The isotopic composition of bulk sediments from this unit is similar to the compositions of clays from Site 323 (Eslinger and Savin, this volume).

At Site 325 , the oxygen isotopic composition of bulk sediments from two horizons was measured. These horizons were sampled only because they contained carbonates (described in the next section). Sample 325-7-2, $54-55 \mathrm{~cm}$ is the noncarbonate portion of a thin nannofossil chalk unit and has a $\delta \mathrm{O}^{18}$ value of +20.0 per mil, similar to the compositions of clay from Site 323. Clay minerals are the dominant constituents of the claystones that underlie the nannochalk unit. In Sample 325$10-3,139-142 \mathrm{~cm}$, a silty and sandy claystone overlies a conglomerate of clay clasts in a calcareous matrix. The isotopic compositions of these (noncarbonate) samples are +8.6 and +9.1 per mil, respectively. These values imply that the dominant components of the sediments are terrigenous detritus.

\section{CARBONATES IN SEDIMENTS}

Carbonates are rare to uncommon in the sediments from Leg 35 . Poorly preserved nannofossil chalks were recovered from Core 16 at Site 323 and from Cores 7 and 8 at Site 325. Trace to minor amounts of foraminifera, generally poorly preserved, are noted at Site 322, Core 11; Site 323, Cores 11-14; Site 324, Cores 5 and 8; and Site 325, Cores 7-10. Authigenic calcite as matrix and cement in siliceous sediment occurs in Cores 11-15 (particularly Core 15) at Site 323 and Cores 5 and 7 at Site 325 . Cores 5 and 7 at Site 323 contain veins of authigenic calcite.

We determined the carbon and oxygen isotopic composition of carbonates from four calcareous zones: two samples of authigenic calcite in silty clay at Section 32313-6, a nannochalk $\left(52 \% \mathrm{CaCO}_{3}\right)$ at Section 325-7-2, and the carbonate matrix in the clay-clast conglomerate at Section 325-10-3. The compositions are listed in Table 2. Relative to typical pelagic carbonate sediment, both the $\mathrm{C}^{13}$ abundance and, to a lesser extent, the $\mathrm{O}^{18}$ abundance of the Leg 35 carbonates are depleted.

The carbon isotopic compositions of the authigenic calcite samples $(-18.4$ to -21.2$)$ are 20 per mil lower than normal pelagic carbonates $(0$ to +2$)$ and are within the range of composition for marine sedimentary organic carbon (Degens, 1969). The dominant source of the (inorganic) carbon in these samples must have been oxidizing organic matter in the sediment. The carbon isotopic composition of the nannochalk is several per mil lower than for induration chalks from the other DSDP cores (J.C. Brenneke, personal communication). Diagenesis of the chalk evidently involved recrystallization and the consequent incorporation of inorganic carbon from pore water that was isotopically depleted. 
The carbon isotopic evidence requires that organic carbon was a principal source of carbon in the authigenic calcites. The obvious source is the reduction of sulfate and the oxidation of organic matter by sulfatereducing bacteria. The organic matter that is oxidized released $\mathrm{CO}_{2}$ (as bicarbonate) and ammonia. Gieskes (1974) points out that sulfate reduction can have important effects on the pore water chemistry of DSDP cores. At sites where sedimentation rates exceed $30-40 \mathrm{~m} / \mathrm{m} . \mathrm{y}$. sulfate concentrations decrease markedly with depth, and both alkalinity and ammonia concentration curves have maxima. These characteristic changes are observed at Sites 323 and 325 (Gieskes, this volume).

Lawrence (1973) has developed a model to evaluate the effect of authigenic carbonate precipitation under these conditions on the carbon isotopic record of bulk carbonates at DSDP Site 148. He assumed (1) that the rate of authigenic calcite precipitation (derived from oxidized organics) is directly related to alkalinity, and is at its maximum in the vicinity of the alkalinity maximum, and (2) that the position of the alkalinity curve with respect to the sediment-water interface has remained fixed through time. Therefore, most of the authigenic calcite will have been precipitated below the depth of the present alkalinity maximum. The predictions of the model fit the observed variations in carbon isotopic composition of the bulk carbonates reasonably well.

Because of the near absence of primary carbonates, it is not possible to apply Lawrence's model to Sites 323 and 325 . However, it is noteworthy that authigenic carbonate in both cores only occurs at depths below the present alkalinity maximum. Another important consequence of the paucity of primary carbonate is that diagenesis and recrystallization of these phases will have little influence on the isotopic composition of dissolved inorganic carbon in pore waters. That the authigenic carbonates at Sites 323 and 325 so clearly indicate contributions from organic carbon is in part a consequence of the scarcity of primary carbonates. This situation is likely to occur in other carbonate-free cores in which sulfate reduction is an important process.

The oxygen isotopic compositions of these carbonates are best interpreted by comparing them to the compositions of calcite in isotope equilibrium with in situ pore waters. Lawrence et al. (this volume) reports a gradient in the oxygen isotopic composition of pore waters of approximately -0.5 per mil $/ 100 \mathrm{~m}$ and -0.3 per $\mathrm{mil} / 100 \mathrm{~m}$ at Sites 323 and 325, respectively. In situ temperatures can be estimated from typical geothermal gradients in oceanic regions. Table 4 gives the equilibrium isotopic composition of calcites at the depth at Sites 323 and 325 where carbonates were sampled. The authigenic calcite from Site 325 appears to be close to isotopic equilibrium with pore water. The calcites from Site 323 are $\mathrm{O}^{18}$ enriched compared to the estimated equilibrium composition.

The equilibrium oxygen isotopic composition of calcite (or any authigenic phase) at a particular horizon will decrease through time for two reasons: First, temperature will increase with increasing depth of burial. Second, if the production of $\mathrm{O}^{18}$-deficient pore waters has been a continuous process, then the $\delta \mathrm{O}^{18}$ value of water at any given horizon will decrease with time (i.e., the oxygen isotopic gradient will remain more or less constant throughout the depositional history of the core). The good agreement between the predicted composition and observed composition of the authigenic calcite from Site 325 suggests that this phase was precipitated relatively recently. If precipitation occurred at a much earlier time, i.e., at a lower temperature and from more $\mathrm{O}^{18}$-enriched water, then the $\delta \mathrm{O}^{18}$ value of this carbonate would be more positive than the predicted equilibrium value. This situation appears to apply to the authigenic carbonates from Site 323 . These phases are close to isotopic equilibrium under conditions that are presently obtained 100 meters higher in the core.

\section{BASALTS AND VEIN-FILLING CARBONATES AT SITE 323}

Ten meters of basalt were recovered at the bottom of Site $323(701-731 \mathrm{~m})$. A detailed description of the basalt is given by Vennum (this volume). This aphanitic holocrystalline basalt consists mainly of augitic pyroxene and intermediate plagioclase; olivine is a minor constituent. Petrographic evidence and drilling rates tentatively suggest that one and possibly two sills were penetrated and that true basement was not reached. There is no evidence for contact metamorphism of the overlying sediments.

The basalt is extensively veined with calcite and composite calcite-clay veins. Fracture surfaces are coated with reddish-brown iron oxide and green clay. Drever (this volume) has identified the clay vein Sample 18-6, $73-83 \mathrm{~cm}$ as a saponite. Veins and fractures vary in width from 0.1 to $10 \mathrm{~mm}$ and are randomly oriented. Brownish staining discolors the rock up to $2 \mathrm{~cm}$ on either side of the larger veins. Amygdules and vesicles occur throughout most of the cores and are generally filled with green clay. No glassy zones, palagonite, or hyaloclastite material were observed.

TABLE 4

Calculated Equilibrium Oxygen Isotopic Composition of Calcite at the Depth Intervals Where Authigenic Calcite was Collected for Analysis

\begin{tabular}{|c|c|c|c|c|c|c|}
\hline \multirow{2}{*}{$\begin{array}{l}\text { Sample } \\
\text { (Interval in } \mathrm{cm} \text { ) }\end{array}$} & \multirow[b]{2}{*}{ Depth (m) } & \multirow{2}{*}{$\begin{array}{l}\text { Est. } \delta 0^{18} \text { of } \\
\text { Pore Water }\end{array}$} & \multicolumn{3}{|c|}{$\begin{array}{l}\text { Est. } \delta 0^{18} \text { of Calcite in Equilib. with } \\
\text { Water Assuming a Thermal Gradient of }\end{array}$} & \multirow{2}{*}{$\begin{array}{l}\text { Observed } \\
\delta 0^{18} \text { of } \\
\text { Calcite }\end{array}$} \\
\hline & & & $3^{\circ} \mathrm{C} / 100 \mathrm{~m}$ & $4^{\circ} \mathrm{C} / 100 \mathrm{~m}$ & $5^{\circ} \mathrm{C} / 100 \mathrm{~m}$ & \\
\hline $323-13-6,36$ & 625 & -3.5 & +25.7 & +24.4 & +23.1 & +26.0 \\
\hline $323-13-6,51$ & 625 & -3.5 & +25.7 & +24.4 & +23.1 & +26.8 \\
\hline $325-10-3,139-142$ & 713 & -2.5 & +26.3 & +24.7 & +23.2 & +24.3 \\
\hline
\end{tabular}


In general, microscopic evidence indicates that alteration of the basalt is not as extensive as megascopic examination would suggest. Plagioclase and pyroxene grains are essentially fresh, and only the olivine grains, which are limited to the lowest part of the section, are extensively altered to calcite. In most samples, less than $5 \%-10 \%$ of the groundmass has been replaced by calcite and clay. However, the groundmass in some of the finer grained zones in Section 18-6 has been transformed to a dark brown, unidentified substance.

The oxygen isotopic compositions of whole-rock samples of basalt from Site 323 range from +6.9 to +11.2 per mil. With the exception of samples from Section $19-2, \delta \mathrm{O}^{18}$ values generally decrease with depth (Figure 6). Muehlenbachs and Clayton (1972) have shown that oxygen isotopic composition is a sensitive indicator of the degree of low-temperature alteration of submarine basalts. They report that fresh basalts having $\mathrm{H}_{2} \mathrm{O}+$ contents of $0.5 \%$ by weight or less have $\delta \mathrm{O}^{18}$ values in the range +5.5 to +5.9 per mil and that $\delta \mathrm{O}^{18}$ values increase withincreasing $\mathrm{H}_{2} \mathrm{O}^{+}$content. Based on this correlation, Muehlenbachs and Clayton have constructed a model in which weathered basalts are considered to be a mixture of fresh basalt and an iron-rich montmorillonite with a $\delta \mathrm{O}^{18}$ value of +27 per mil and an $\mathrm{H}_{2} \mathrm{O}^{+}$content set arbitrarily at $10 \%$. The model fits their data well, especially where hydration is not extensive.

Since we have no data on the water content of our samples, we cannot rigorously fit our isotopic results to this model. (Preliminary shipboard results give total water content as about $1 \%$; the samples were not identified.) Based only on changes in isotopic composition, the alteration of basalts at Site 323 varies from $5 \%$ to $25 \%$. These values seem high in light of the preliminary petrographic evidence described above. However, all of the whole-rock samples we analyzed were within a few centimeters of veins and thus may be more altered than typical samples. In this regard, however, a criterion for alteration based solely on color change is not reliable. Drever (this volume) reports no significant difference between the chemical composition of a reddish-brown stained "altered" basalt and of a gray "fresh" basalt" in Sample 18-6, 14-15 cm. The chemical compositions reported by Donnelly (this volume) on "fresh" and "altered" specimens of basalt from the same sample and from Sample 19-2, 144-146 cm are also essentially the same. The oxygen isotopic compositions of the "fresh" and "altered" basalt from Sample 19-2, 144-146 cm are +7.6 and +7.8 per mil, respectively (Figure 3). In Sample $19-2,140 \mathrm{~cm}$ the isotopic composition of brownstained basalt immediately adjacent to a vein $(+7.0$ per mil) is lighter than the composition of the unstained portion further from the vein $(+7.7$ per mil). Thus, color difference does not reflect any major difference in degree of chemical or isotopic alteration.

Muehlenbachs and Clayton (1972) estimate that submarine basalts which are continuously exposed to seawater are progressively enriched in $\mathrm{O}^{18}$ at the rate of 0.25 per mil/ $10^{6} \mathrm{yr}$. The rate of alteration at Site 323 is only $10 \%-30 \%$ of this value, assuming that the basalts have a minimum age of $70 \mathrm{~m} . \mathrm{y}$. This lower rate is probably related to the restricted communication via fractures between the bulk of the basalt and ocean water, i.e., water/rock ratios have been very low. Restricted communication and decreasing accessibility of seawater could also account for the decreasing $\delta \mathrm{O}^{18}$ (decreasing alteration) with depth. However, sampling of basalts from Site 323 was biased, not only because whole-rock samples were taken close to vein-filled fractures, but also because recovery in the lower 20 meters was poor (see Figure 6). It is possible that the missing intervals contained considerable altered basalt. Thus, it is premature and not warranted by our limited data to conclude that the low-temperature alteration of oceanic basalt decreases in the uppermost few tens of meters. Nonetheless, this possibility has important and farreaching implications and should be tested in more continuous cores of basalt.

The isotopic composition of secondary vein-filling material can provide important information regarding the conditions of alteration of the host basalt and the nature of the fluids involved in the genesis of veins. Calcite is the most abundant vein-filling mineral. Since it precipitated directly from solution, the oxygen isotopic composition of the vein calcites places limits on the temperature of vein formation and on the isotopic composition of the vein-forming solutions. For example, if the calcite veins precipitated in isotopic equilibrium with normal seawater $(0$ per mil), then the calculated temperatures of formation were from $13^{\circ}$ to $39^{\circ} \mathrm{C}$ (Craig, 1965; O'Neil et al., 1969). If the veins were precipitated from $\mathrm{O}^{18}$ - deficient water of, for example $\mathbf{- 3 . 5}$ per mil, the corresponding temperatures were from $0^{\circ}$ to $22^{\circ} \mathrm{C}$. Figure 6 shows that the variation with depth in the oxygen isotopic composition of calcite veins is inversely related to the depth variation in the composition of basalts. Specifically, calcite veins with low $\delta \mathrm{O}^{18}$ values are associated with basalts of high $\delta \mathrm{O}^{18}$ values, and conversely. This inverse correlation is particularly evident in the lower part of Core 19, Section 4, where carbonates are more $\mathrm{O}^{18}$-rich and basalts are more $\mathrm{O}^{18}$-poor than in almost any other vein-bearing horizon we analyzed. This correlation strongly suggests that a genetic relationship exists between the isotopic composition of the calcite veins and the low-temperature alteration of the basalts.

Based on these observations, we tentatively propose the following model of calcite vein genesis: Submarine weathering of basalt in closed systems depletes the $\mathrm{O}^{18}$ content of participating seawater (Lawrence, 1973; Lawrence et al., 1975). The extent of the depletion is primarily a function of the water/rock ratio. Because of restricted intercommunication of fluids in the fracture network of basalts, low-temperature alteration proceeds in a series of more-or-less isolated water-rock systems. At some stage in this alteration, the fluids in some of the fractures become supersaturated with respect to calcite, and precipitation occurs. Since alteration and isotopic exchange occurred in relatively closed systems, the oxygen isotopic composition of vein calcites will reflect the degree of local alteration. The more extensive the alteration, the lower the $\mathrm{O}^{18}$ content of the vein calcite.

In Sample 19-2, 144-146 cm two calcite veins occur; the relative age of the veins is evident from a crosscutting relationship (Figure 3 ). The younger vein (Sample 6) is 2 per mil depleted in $\mathrm{O}^{18}$ with respect to the 
older vein (Sample 4). This age-O ${ }^{18}$ content relationship is consistent with our model, assuming that the veins represent a succession in the degree of alteration of surrounding basalt.

This model is not applicable to the overall lowtemperature weathering of basalt. The generation of calcite veins represents only one stage in this alteration process-alteration did not cease after the precipitation of calcite veins. Almost certainly, overall alteration has not been limited to a series of isolated water-rock systems, but has involved some communication with seawater through, at least in later stages, the interstitial pore water in overlying sediments. The amount of $\mathrm{O}^{18}$. deficient pore waters in the sediments at Site 323 requires contributions from the weathering of basalts as well as from the diagenesis of volcanogenic sediment (Lawrence et al., this volume). Although this model (like most models) is an oversimplification of the natural situation, it can explain the isotopic relationships between calcite veins and weathered basalts at Site 323 .

The carbon isotopic composition of calcite veins may provide additional clues regarding their genesis. Throughout most of the core, compositions fall in the narrow range of +1.8 to +2.4 per mil, suggesting that the isotopic composition of dissolved inorganic carbon in the vein-forming solutions were uniform and similar to that of normal seawater. The uppermost calcite veins, from $18-6,78-83 \mathrm{~cm}$, have $\delta \mathrm{C}^{13}$ values of -2.4 and -3.0 per mil. The most likely source of isotopically light carbon in this instance is from the pore waters in overlying sediments. As we discussed previously, bacterogenic oxidation of organic matter will release $\mathrm{C}^{13}$-deficient bicarbonate to pore waters in the sediment. If solutions in the uppermost part of the basalt were in at least partial communication with sedimentary pore waters of this type, vein calcites with low $\delta \mathrm{C}^{13}$ values can be explained. This explanation implies that the veins in $18-6,73-83 \mathrm{~cm}$ were formed after the accumulation of a moderate thickness of sediments, since alkalinity maxima occur some tens of meters below the sediment-water interface. This limitation is not inconsistent with the model of oxygen isotopic compositions of the veins. The low $\delta \mathrm{O}^{18}$ values in $18-6,73-83 \mathrm{~cm}$ suggest an extended period of local alteration, thereby increasing the likelihood of mixing between solutions in the basalt and pore waters in sediments.

The oxygen isotopic composition of clay veins can also be used, at least in principle, to define the conditions of alteration and vein formation. Recently, Yeh (1974) has estimated smectite-water fractionation factors at sedimentary temperatures. Using these values, the clay veins are in equilibrium with water of 0 per mil at $32^{\circ}$ to $59^{\circ} \mathrm{C}$, or about $20^{\circ} \mathrm{C}$ higher than the isotopic temperatures of the calcite veins. This apparent discrepancy may be due to the fact that Yeh's estimates were evidently made for iron-free phases, and thus may not be applicable to the clay veins. The iron content (as weight percent $\mathrm{Fe}_{2} \mathrm{O}_{3}$ ) of the saponite vein from Sample $18-6,14-15 \mathrm{~cm}$ is $7.2 \%$ (Drever, this volume), and it is likely that the other veins have similarly high iron contents. In a study of continental weathering, Lawrence and Taylor (1972) show that isotopic fractionation between montmorillonite and water decreases with in- creasing iron content. Montmorillonites with 7\%-8\% $\mathrm{Fe}_{2} \mathrm{O}_{3}$ are approximately 3 per mil depleted in $\mathrm{O}^{18}$ with respect to montmorillonites in the same horizon with lower iron contents. If we apply a 3 per mil correction to Yeh's (1974) smectite-water isotopic geothermometer, then the clay veins are in equilibrium with water of 0 per mil at $17^{\circ}-40^{\circ} \mathrm{C}$ and with water of -3.5 per mil at $2^{\circ}$ $22^{\circ} \mathrm{C}$. These temperatures are in good agreement with the calcite-water isotopic temperatures. Given the uncertainties involved in the estimation of clay-water temperatures, they should be interpreted with caution.

\section{CONCLUSIONS}

1. The oxygen isotopic composition of most of the bulk sediments from Sites 322, 323, and 325 indicates a terrigenous source.

2. Oxygen isotopic fractionation between claystones and "chert" in Cores 8-10 of Site 323 confirms that the cherts were formed by the mobilization and reprecipitation of biogenic silica.

3. The enrichment of $\mathrm{O}^{18}$ in the basal brown claystone at Site 323 is consistent with chemical and mineralogical evidence suggesting that these sediments are predominantly the low-temperature alteration products of volcanogenic debris.

4. Authigenic calcites at Sites 323 and 325 were precipitated from pore solutions having carbon (as dissolved bicarbonate) and oxygen isotopic compositions significantly different from those of typical seawater. Most of the dissolved carbon in the pore waters was derived from the oxidation of organic matter. The oxygen isotopic compositions of the calcite implies that they were precipitated at equilibrium with $\mathrm{O}^{18}$-depleted marine pore waters at temperatures at or near the present depth of burial. Thus, the isotopic evidence suggests that these calcites are late diagenetic products.

5. The upper 30 meters of basalt at Site 323 has undergone some degree of isotopic alteration, probably as a result of low-temperature submarine weathering. This alteration generally decreases with depth, suggesting that accessibility to seawater may be a controlling factor.

6. The oxygen isotopic compositions of calcite veins in the basalt indicate a low-temperature origin and are inversely correlated with the isotopic composition of basalt adjacent to the veins. This suggests that the veins were precipitated from solutions which were isotopically depleted by interaction (weathering) with basalt in closed systems. The carbon isotopic evidence suggests that only the uppermost veins were precipitated from solutions reflecting organic carbon contributions, possibly by mixing with overlying sediment pore water.

7. Clay veins in the basalt yield oxygen isotopic temperatures in agreement with calcite temperatures provided that the high iron content of the clays is taken into account.

\section{ACKNOWLEDGMENTS}

Discussions with other members of the Leg 35 Geochemistry group (T. Donnelly, J. Drever, E. Eslinger, J. Gieskes, M. Kastner, and E. Perry) were particularly useful in formulating many of our interpretations. The financial assistance provided by the DSDP that permitted this group to 
assemble in Laramie, Wyoming, in October 1974 to present data and discuss their implications is gratefully acknowledged. The isotope geochemical laboratory at the University of Illinois is supported in part by NSF Grant GA-1680. The isotopic analyses undertaken at Lamont-Doherty Geological Observatory were supported by NSF Grants GA-17724 and DES-75-02968.

\section{REFERENCES}

Anderson, T.F., in preparation. Stable isotopic evidence for the origin of carbonate veins in oceanic volcanics.

Clayton, R.N. and Mayeda, T.K., 1963. The use of bromine pentafluoride in the extraction of oxygen from oxides and silicates for isotopic analysis: Geochim. Cosmochim. Acta, v. 27 , p. $43-52$.

Craig, H., 1965. The measurement of oxygen isotope paleotemperatures. In Tongiorgi, E. (Ed.), Spoleto Conf. on Stable Isotopes in Oceanographic Studies and Paleotemperatures Proc.: v. 3, p. 1-24.

Degens, E.T., 1969. Biogeochemistry of stable carbon isotopes. In Eglinton, G. and Murphy, M.T.J. (Eds.), Organic geochemistry: New York (Springer-Verlag), p. 304-329.

Gieskes, J.M., 1974. Insterstitial water studies, Leg 25. In Simpson, E.S.W., Schlich, R., et al., Initial Reports of the Deep Sea Drilling Project, Volume 25: Washington (U.S. Government Printing Office), p. 361-394.

Jackson, M.L., 1956. Soil chemical analysis-advanced course: Madison (Univ. of Wisconsin, Department of Soils).

Knauth, L.P. and Epstein, S., 1975. Hydrogen and oxygen isotope ratios in silica from the JOIDES Deep Sea Drilling Project: Earth Planet. Sci. Lett,, v. 25, p. 1-10.
Kolodny, Y. and Epstein, S., 1974. The stable isotope record of DSDP cherts (abstract): Trans. Am. Geophys. Union, v. 55, p. 456 .

Lawrence, J.R., 1973. Interstitial water studies, Leg 15-Stable carbon and oxygen isotope variations in water, carbonates, and silicates from the Venezuela Basin (Site 149) and the Aves Rise (Site 148). In Heezen, B.C., MacGregor, I., et al., Initial Reports of the Deep Sea Drilling Project, Volume 10: Washington (U.S. Government Printing Office), p. 891-899.

Lawrence, J.R. and Taylor, H.P., Jr., 1972. Hydrogen and oxygen isotope systematics in weathering profiles: Geochim. Cosmochim. Acta, v. 36, p. 1377-1393.

Lawrence, J.R., Gieskes, J.M., and Broecker, W.S., 1975. Oxygen isotope and cation composition of DSDP pore waters and the alteration of Layer II basalts: Earth Planet. Sci. Lett., v. 27, p. 1:10.

McCrea, J.M., 1950. On the isotopic chemistry of carbonates and a paleotemperature scale: J. Chem. Phys., v. 18, p. 849857.

Mopper, K. and Garlick, G.D., 1971. Oxygen isotope fractionation between biogenic silica and ocean water: Geochim. Cosmochim. Acta, v. 35, p. 1185-1187.

Muehlenbachs, K. and Clayton, R.N., 1972. Oxygen isotope studies of fresh and weathered submarine basalts: Canadian J. Earth Sci., v. 9, p. 172-184.

O'Neil,.J.R., Clayton, R.N., and Mayeda, T.K., 1969. Oxygen isotope fractionation in divalent metal carbonates: J. Chem. Phys., v. 51 , p. 5547-5558.

Savin, S.M. and Epstein, S., 1970. The oxygen and hydrogen isotope geochemistry of ocean sediments and shales: Geochim. Cosmochim. Acta, v. 34, p. 43-63.

Yeh, H.W., 1974. Oxygen isotope studies of ocean sediments during sedimentation and burial diagenesis: $\mathrm{Ph}$. $\mathrm{D}$. thesis, Case Western Reserve University. 